\title{
Research on Supply Side Structural Reform in China from the Perspective of Multiple Streams Theory
}

\author{
Yijia Guo, Tianxue Li \\ Beijing Normal University, Beijing, China \\ Email: guoyijia1999@163.com
}

How to cite this paper: Guo, Y.J. and Li, T.X. (2018) Research on Supply Side Structural Reform in China from the Perspective of Multiple Streams Theory. Open Journal of Social Sciences, 6, 104-110. https://doi.org/10.4236/jss.2018.612010

Received: November 26, 2018

Accepted: December 17, 2018

Published: December 20, 2018

Copyright ( $\odot 2018$ by authors and Scientific Research Publishing Inc. This work is licensed under the Creative Commons Attribution International License (CC BY 4.0).

http://creativecommons.org/licenses/by/4.0/

\begin{abstract}
From the perspective of multi-source flow theory, this paper explores the process of setting up the policy agenda for China's supply-side structural reform. It began discussions by combining social issues such as the decline in economic indicators and the decline of the energy industry with changes in the political environment jumping out of the traditional perspective of a single economic analysis. At the same time, this article focuses on the role of the supply school in policy advice. From the three aspects of issues, policies, and politics, it explores the opening of the policy window.
\end{abstract}

\section{Keywords}

Supply-Side Structural Reform, Multi-Source Flow Theory, Policy Analysis

\section{The Background of Policy Evolution}

The supply side reform was designed to improve the quality and efficiency of the supply system and enhance the momentum of sustained economic growth when it was first officially proposed in China [1]. On November 10, 2015, Xi Jinping proposed the "supply-side structural reform" for the first time at the Central Financial and Economic Leading Group meeting. In the following 8 days, the "supply-side reform" was mentioned at three meetings that include the State Council executive meeting, the Asia-Pacific Economic Cooperation Organization meeting and the "13th Five-Year Plan" drafting work meeting. The Central Economic Work Conference, which closed on December 21, 2015, emphasized that promoting structural reforms on the supply side are a major innovation that adapts to and leads the new normal of economic development, and is an active choice to adapt to the new situation of comprehensive national strength compe- 
tition after the international financial crisis. On December 21, 2015, Xi Jinping once again pointed out that the focus of economic work in 2016 is to implement the "13th Five-Year Plan" proposal and promote the supply side structural reform. At the twelfth meeting of the Central Financial and Economic Leading Group, it was further proposed that the plan of supply-side reform needs five "clear". On January 27, 2016, the Central Committee issued the No. 1 Document "Several Opinions on Implementing the New Concept of Development and Accelerating Agricultural Modernization to Achieve the Comprehensive Well-off Society" that included the view of "Supply-side Reform" into the central No. 1 document for the first time. Later, Guangdong province and other places have issued relevant policy programs, marking the formal entry of the supply-side reform policy into the implementation phase. At the end of February 2016, the Guangdong Provincial Government officially issued the "Guangdong Province Supply Side Structural Reform Overall Plan (2016-2018)" and six action plan documents such as capacity reduction, destocking, deleveraging and cost reduction. Guangdong has set a timetable and road map for "going down" in three years. By the end of 2016, all the relevant enterprises in the province will be cleared; at the end of 2017, the state-owned and extremely poor enterprises in the province will basically get out of trouble; in terms of capacity, by the end of 2018, the market will basically be cleared of "zombie enterprises".

\section{Multi-Source Analysis of Supply-Side Structural Reform}

\subsection{The Source of Problem}

The source of the problem is the process of mining and confirming the problem. In this process, policy makers pay attention to issues that are missing and not being concerned, in addition to the issues they are concerned about [2]. Thomas Dey once said, "It is more important to know what the problem is than to find the answer to the problem." A correct understanding of the problem is the first step for policy makers to make the right decisions.

\subsubsection{Changes in Economic Indicators}

Chinese government policy makers generally monitor social dynamics, especially macroeconomic operations, through changes in indicators. Therefore, the development disadvantage of some major economic indicators in the past decade has become an important issue for government officials, which has provided a powerful impetus for follow-up reform. In the market operation before the supply-side reform, the relevant indicators of GDP and energy consumption have become two important indicators that reflect the overall decline of China's economic operation and the urgent need to improve the economic structure and production methods.

China's GDP growth rate continued to decline before the reform: $10.6 \%$ in 2010 and $9.5 \%$ in 2011 , and continued to decline to $6.9 \%$ in 2015. Chinese economic growth showed a significant slowdown. After the gradual implementation of the reform, the GDP of the tertiary industry has achieved sustained growth 
that showed the importance of reform for the optimization of industrial structure. At the same time, according to the 2010 WEC data, China's total economic energy consumption in 2008 is 1.5 times higher than the world average, 2 times higher than Brazil, 1.6 times higher than the US, 2.2 times higher than Japan, and 1.4 times higher than India. At the same time, according to the data provided by BP, the World Energy Statistics 2011, the world's energy-consuming countries are no longer the United States, but replaced by China. It can be seen that China's economic development is based on huge energy consumption. This resource-dependent economic development is unsustainable, so reform is imperative.

\subsubsection{The Policy of Demand Regulation Is Not Effective}

Since the market economy reform was fully promoted, the Chinese government's macroeconomic regulation and control has been dominated by demand regulation [3]. But in recent years, demand regulation policies have not been effective. Between 2006 and 2007, the Chinese economy experienced severe inflation, and the government suppressed aggregate demand by tightening policies such as the statutory reserve ratio. When the US financial crisis broke out in 2008, China began to turn to expansionary monetary policy and fiscal expenditure policy. In the first half of 2012, the Chinese government stimulated market demand in various ways, and in the second half of the same year, it faced inflation again. Chinese economy has been in a state of turmoil under demand-based regulation, which has placed an urgent need on the reform of regulation and control.

\subsubsection{Outstanding Focus: The Decline of Traditional Energy Industry}

In December 2015, the 62\% iron ore price of Qingdao Harbour fell to the lowest point in the single-day data record since 2009. The iron ore price has reached a new low, which is a microcosm of overcapacity in China's traditional industries. Since 2012, the "golden decade" of the coal economy has ended, and the coal-based energy industry in Shanxi Province has rapidly turned into a trend, and the provincial economic growth rate has been low. The steel industry in Hebei Province entered a period of recession and a large number of factories closed down. The old industrial bases in Northeast of China are also facing a series of risks such as deflation, unemployment and insufficient economic power brought about by the decline of traditional industries. The decline of the traditional industry has brought about a huge threat to the economic operation and the people's livelihood, which has made the industrial structure transformation increasingly prominent.

\subsection{The Source of Policy}

The source of policy is the expression and proposition of professional opinions on public issues. After identifying the problem, what is to be done is the design and choice of the alternatives to solve the problem. The source of policy is ac- 
tually the clarification of the process of producing policy options and policy recommendations by specific groups such as experts and scholars [4]. While pushing the issue into the policy agenda is not something that can be done with a viable alternative, the chances of the issue being put on the policy agenda will be greatly improved if there is a problem with the corresponding solution. Therefore, the source of policy is a key step in policy establishment. In the promotion of supply-side structural reforms in China, the new supply school promotes decision-making as a professional think tank.

New supplyist economics is based on the basis of China's reform practice. It proposes the theoretical basis of the new supply cycle, the system theory of the three major supply constraints, and the long-term reform proposition of the five major sources of wealth. These theories emphasize the far-reaching impact of the supply structure on the economic structure and provide a theoretical basis for supply-side reforms [5]. On this basis, the new supply school mainly expands the influence of new supplyist economics through expert seminars, internal reference reports, seminars and other forms.

\subsection{The Source of Political}

The source of politics is the influence of political factors on problem solutions. It refers to the promotion of the state of the agenda or the use of the state's emotional changes, organized political power, government change, partisan ideology, and social class structure. In the promotion of China's supply-side structural reforms, the CPC's people-oriented ruling philosophy is the core support. At the same time, the transformation of the role of the new central leadership group and the role of the central financial leadership group has brought about an opportunity, and the people's reform enthusiasm and the mass media have played an important role.

\subsubsection{The Ruling Philosophy of the Communist Party of China}

The main factor in China's political resources is the ruling philosophy of the Communist Party of China. The Communist Party of China is China's ruling party. This determines that the dominant factor in the political source is the party's ruling philosophy, and the process of China's entire policy is directly guided and influenced by it. The Communist Party of China has always adhered to the core ruling philosophy of building the party for the public and governing for the people. Its basic mission is to continuously explore strategic measures to promote the sound and rapid development of the national economy in order to achieve the goal of building a well-off society in an all-round way. Under the situation that the country's economic development is in a downturn, the industry is uneven, and the regional imbalance is prominent, the Chinese Communist Party is actively seeking effective measures to get out of the predicament. This is in line with the requirements of the party's ruling philosophy.

\subsubsection{The Change of the Chinese Central Leadership}

In March 2013, China's new generation of central leaders confirmed and Xi 
Jinping was the core figure. The new leadership also brought new ideas and created political conditions for supply-side reform. After the new leadership team came to power, the central government facilitated the announcement that the "CPC Central Committee's decision on comprehensively deepening reforms of several major issues" on November 15, 2013, which is the transformation of long-term demand intervention thinking. It has laid the foundation for the supply of reform.

\subsubsection{The 18th Central Financial and Economic Leading Group}

The Central Financial and Economic Leadership Group is one of the organizational forms for the Communist Party of China to lead economic work. On March 17, 1980, the Central Financial and Economic Leadership Group was formally established and became the deliberative body of the Party Central Committee to lead economic work. On April 17, 2013, the first meeting of the 18th Central Financial and Economic Leading Group was held to announce the establishment of the new Central Financial and Economic Leading Group and clarify the positioning of the new Financial Leadership Group. It is an institution commissioned by the Political Bureau of the Central Committee and its Standing Committee to make major strategic policy decisions for economic and social development. From the deliberative body to the decision-making body, the change of the orientation of the central financial and economic leadership group highlights the importance attached by the Party Central Committee with Comrade $\mathrm{Xi}$ Jinping as the core to strengthening economic work leadership. The repositioned central financial leadership team played a major role in the development of supply-side reform policies.

\subsubsection{Public Opinion on the Expectation of Reform}

Driven by the emergence of problems, the government's reform proposals, and the ideas of experts and scholars, the participation and attention of the public in the reforms has never been higher. Faced with the imbalance between regions and industries, the people are looking forward to a wide range of effective reforms in the face of the decline of traditional industries. At the same time, Xi Jinping also emphasized that "we must respond positively to the strong appeal and ardent expectations of the broad masses of the people for deepening reform and opening up" at the second collective study meeting of the Political Bureau of the CPC Central Committee.

\subsubsection{The Influence of the Mass Media}

The mass media as the disseminator of information also affects the formulation of policies. The media intentionally or unintentionally acted as a shaper of public opinion and a propagandist of government policies, that indirectly prompting a large number of government officials to turn the views of the media into policies. On the one hand, experts and scholars supply new ideas of school reform to promote communication, and the central government expects that the goal of deepening reform will also reach the bottom people through the mass media. 
This creates a paradox among the people, and the mass media has built a bridge between the people's vision of reform and the upper-level thinking.

\subsection{Opening of the Policy Window}

The policy window gives the proponent a so very good opportunity to showcase the special issues that can be raised. When there are compelling issues or a strong political flow, the window of policy will be opened. In the process of supply-side structural reform, the establishment of a new generation of leading groups provides a rare opportunity for the coupling of the three major sources that opens the window for this reform. In the process of launching the supply-side reform policy, the warning of economic indicators such as GDP, the weakness of the current "demand side" policy, and the huge problems in the traditional industry have led to the formation of problems. The focus incidents also directly affected the changes in political flows. For example, in the context of economic downturns and industry decline, the voice of the people demanding reforms is high. In 2013, the new leadership team came to power, the unprecedented enthusiasm for reform of the people and the influence of public opinion media constituted a political source. At the same time, the development of new supply school ideas has promoted the formation of policy flows. The emergence of a series of economic problems and the government's re-election opened the window of policy, the three sources officially gathered together, and the supply-side reform policy was successfully launched.

Under the influence of the supply-side reform, China's tertiary industry has entered an accelerated development period, and its technological innovation capability has been continuously improved. With the continuous improvement of the adaptability and flexibility of the economic structure, the reform goal of improving the efficiency of resource allocation is gradually being realized.

\section{Summary}

Looking at China's policy agenda from the perspective of multi-source flow, its three sources are not independent each other, especially the political flow and policy source. In the formation of China's supply-side structural reform policy, the supply school has made a major contribution as the backbone of the policy flow, but they have a close and inseparable relationship with the political flow. Many scholars of the supply school not only make suggestions as think tanks, but also participate in profound political affairs as state officials.

The boundary between political flow and policy flow is not clear, and it also reflects a serious problem that the political flow in China has a profound impact on policy flow. The relationship between the development of the supply school and the political situation has not only been discussed in depth, but we can see the profound influence of the political source on the development of policy thinking from the intertwining of the source and the flow. This can reflect that the agenda of China's policy is not perfect compared to the West. There are few 
professional think tanks representing the origin of policy in China, and most of the existing think tanks have an official background.

\section{Conflicts of Interest}

The authors declare no conflicts of interest regarding the publication of this paper.

\section{References}

[1] Wen, J.D. and Song, B. (2016) Supply-Side Structural Reform: The Inevitable Choice of Economic Development. Journal of Xinjiang Normal University (Philosophy and Social Sciences Edition), 37, 20-27.

[2] Zhang, H.Z. (2016) Multi-Source Analysis of Local Policy Agenda Setting-Taking Yiwu Taxi Reform as an Example. Journal of Wuhan University of Science and Technology (Social Science Edition), 18, 135-141.

[3] Ge, X.B. and Fu, X.Q. (2017) Analysis on the Policy Agenda of Supply Side Structural Reform of Preschool Education under the Perspective of Multi-Source Flow. Educational Development Research, 37, 43-50.

[4] Kingdon, J.W. (2004) Agenda, Options and Public Policy. Renmin University of China Press, Beijing.

[5] Liu, W. (2016) The New Normal of Economy and the Structural Reform of Supply Side. Management World, No. 7, 1-9. 